Neurosurg Focus 26 (5):E5, 2009

\title{
Giant serpentine aneurysms
}

\author{
Lana D. Christiano, M.D., Gaurav Gupta, M.D., \\ Charles J. Prestigiacomo, M.D., F.A.C.S., and Chirag D. Gandhi, M.D. \\ Department of Neurological Surgery New Jersey Medical School, \\ University of Medicine and Dentistry of New Jersey, Newark, New Jersey
}

\begin{abstract}
Segal and McLaurin first described giant serpentine aneurysms, based on their distinct angiographic features, in 1977. These lesions are $\geq 25 \mathrm{~mm}$, partially thrombosed aneurysms with a patent, serpiginous vascular channel that courses through the aneurysm. There is a separate inflow and outflow of the aneurysm, of which the outflow channel supplies brain parenchyma in the territory of the parent vessel. Given the large size, unique neck, and dependent distal vessels, these aneurysms pose a technical challenge in treatment. Initial management has included surgical obliteration, but as endovascular techniques have evolved, treatment options too have expanded. In this review the authors attempt to summarize the existing body of literature on this rare entity and describe some of their institutional management strategies. (DOI: 10.3171/2009.2.FOCUS0918)
\end{abstract}

KEY WORDS • giant serpentine aneurysm $\quad \bullet \quad$ clinical presentation
radiographic features
$\bullet \quad$ natural history

$\mathrm{T}$ The term "giant serpentine aneurysm" was first coined by Segal and McLaurin. ${ }^{39}$ In 1977 they published a report of 2 cases and a literature review involving 4 additional cases of giant aneurysms with distinct angiographic features. Angiographically, they noted a giant aneurysm $>25 \mathrm{~mm}$ in diameter that was partially thrombosed and had a residual serpiginous vascular channel. They also noted that the flow rate coursing through the aneurysm was slow, and the aneurysm ended in a distal branch of the feeding artery and caused mass effect. Since 1977, giant serpentine aneurysms have been considered a subcategory of giant aneurysms. ${ }^{39}$

Traditionally, patients with these lesions have undergone placement of an aneurysm clip, with or without thrombectomy. The perioperative morbidity and mortality rate, however, was $30-35 \% .^{1}$ These patients were suffering debilitating strokes due to the abrupt cessation of cortical blood flow through the serpentine aneurysm. Improved outcomes were seen when revascularization procedures were added to the surgical treatment armamentarium. More recently, endovascular so-called deconstructive procedures, which obstruct flow through the aneurysm, have been described. Giant serpentine aneurysms are technically challenging entities and each case should be considered on an individual basis. In this review

\footnotetext{
Abbreviations used in this paper: $\mathrm{ACA}=$ anterior cerebral artery; $\mathrm{BTO}=$ balloon test occlusion; EEG = electroencephalography; ICA $=$ internal carotid artery; $\mathrm{MCA}=$ middle cerebral artery; $\mathrm{PCA}=$ posterior cerebral artery; $\mathrm{SAH}=$ subarachnoid hemorrhage; $\mathrm{STA}=$ superficial temporal artery.
}

we attempt to summarize the existing body of literature on this rare entity and provide some of our institutional management strategies.

\section{Clinical Presentation}

Patients with giant serpentine aneurysms often present with signs of mass effect. Distinct symptomatology is based on the location of the aneurysm. As 50\% of giant serpentine aneurysms are in the MCA territory, common presenting symptoms include headache, nausea and vomiting, hemiparesis, dysphasia/aphasia, and seizure. ${ }^{1}$ Other symptoms noted in the literature include visual disturbance, cranial nerve palsy, papilledema, mental deterioration or depression, dysesthesia, and vertigo (Table 1). ${ }^{1}$ According to Suzuki et al., ${ }^{41} 28 \%$ of patients present with $\mathrm{SAH}$ and the typical associated headache.

\section{Radiographic Characteristics}

Angiographically, the features of giant serpentine aneurysms are still very similar to those originally described by Segal and McLaurin. ${ }^{39}$ The aneurysm is $>25 \mathrm{~mm}$ in diameter, is partially thrombosed, and contains a tortuous intraaneurysmal vascular channel. . $^{1,5,8,11,25,33,39,44}$ The intraaneurysmal vascular channel is often eccentrically located within the aneurysmal mass and takes a wavy, sinusoidal course - hence, the term "serpentine." 29,33 The eccentrically located vascular channel forms as a result of the Coanda effect, a hemodynamic principle describing jet blood flow forces that direct and reinforce blood 
TABLE 1: Summary of data obtained in a literature review of cases involving giant serpentine aneurysms*

\begin{tabular}{|c|c|c|c|c|c|c|}
\hline Authors \& Year & $\begin{array}{l}\text { Age (yrs), } \\
\text { Sex }\end{array}$ & Location & Size (cm) & Presentation & Treatment & Outcome \\
\hline Sadik et al., 1965 & $47, M$ & rt MCA & $\begin{array}{l}8.5 \times 5.5 \\
\quad \times 5\end{array}$ & $\begin{array}{l}\text { HA, decreased visual acuity, It } \\
\text { hemiparesis }\end{array}$ & resection & died POD 7 \\
\hline $\begin{array}{l}\text { Cantu \& LeMay }{ }^{6} \\
1966\end{array}$ & $58, M$ & rt MCA & $\begin{array}{l}8 \times 5.5 \\
\times 5.5\end{array}$ & $\begin{array}{l}\text { HA, dysnomia, dyscalculia, dys- } \\
\text { praxia, finger agnosia }\end{array}$ & clipping \& resection & dysphasia \\
\hline $\begin{array}{l}\text { Terao \& Muraoka, } \\
1972\end{array}$ & $67, \mathrm{M}$ & It MCA & $\begin{array}{c}8 \times 5.5 \\
\times 6\end{array}$ & HA, dysphasia, It hemiparesis & aspiration curettage & died POD 6 \\
\hline \multirow[t]{2}{*}{ Lukin et al., 1975} & $67, \mathrm{M}$ & It MCA & 6 & $\begin{array}{l}\text { HA, expressive dysphasia, rt } \\
\text { hemiparesis }\end{array}$ & surgical wrapping & $\begin{array}{l}\text { expressive dysphasia, } \\
\mathrm{rt} \text { hemiparesis }\end{array}$ \\
\hline & $30, M$ & It MCA & & $\begin{array}{l}\text { HA, dysarthria, rt hemiparesis, } \\
\text { central CN VII palsy }\end{array}$ & resection & diplopia \\
\hline \multirow[t]{2}{*}{$\begin{array}{l}\text { Segal \& McLaurin, } \\
1977\end{array}$} & $39, \mathrm{M}$ & rt MCA & $\begin{array}{c}3.8 \times 3.6 \\
\times 2\end{array}$ & HA, blurred vision, papilledema & resection & $\begin{array}{l}\text { It homonymous hemi- } \\
\text { anopsia }\end{array}$ \\
\hline & $30, \mathrm{M}$ & It MCA & $\begin{array}{l}6.5 \times 6 \\
\times 5\end{array}$ & $\begin{array}{l}\text { HA, aphasia, central CN VII palsy, } \\
\text { rt hemiparesis, receptive aphasia }\end{array}$ & resection & persistent diplopia \\
\hline $\begin{array}{l}\text { Ammerman \& } \\
\text { Smith, } 1977\end{array}$ & $20, M$ & It MCA & & seizure, rt hemiparesis & $\begin{array}{l}\text { STA-MCA anastomosis, } \\
\text { aneurysm trapping }\end{array}$ & seizure disorder \\
\hline Fodstad et al., 1978 & $27, \mathrm{~F}$ & It ICA & 7.5 & $\begin{array}{l}\text { diplopia, partial CN III \& VI palsy, } \\
\text { hemifacial paresthesias }\end{array}$ & $\begin{array}{l}\text { It ICA ligation, partial resec- } \\
\text { tion }\end{array}$ & $\begin{array}{l}\text { partial It ophthal- } \\
\text { moplegia, CN V palsy }\end{array}$ \\
\hline $\begin{array}{l}\text { Pinto et al., } \\
1979\end{array}$ & & rt ICA & & diplopia & & \\
\hline $\begin{array}{l}\text { Tomasello et al., } \\
1979\end{array}$ & $40, M$ & rt MCA & $\begin{array}{l}6.5 \times 5 \\
\times 4.5\end{array}$ & $\begin{array}{l}\text { HA, central CN VII palsy, It hemi- } \\
\text { paresis }\end{array}$ & $\begin{array}{l}\text { surgical aneurysmal trapping } \\
\& \text { resection }\end{array}$ & neurologically intact \\
\hline Patel et al., 1981 & $33, \mathrm{~F}$ & rt MCA & & $\begin{array}{l}\text { HA, It hemiparesis, It homonymous } \\
\text { hemianopsia }\end{array}$ & $\begin{array}{l}\text { common carotid artery oc- } \\
\text { clusion }\end{array}$ & $\begin{array}{l}\text { It hemiparesis, It } \\
\text { hemianopsia }\end{array}$ \\
\hline $\begin{array}{l}\text { Fukamachi et al., } \\
1982\end{array}$ & $48, F$ & It PCA & $6 \times 5 \times 4$ & HA, rt hemiparesis, rt hemianopsia & $\begin{array}{l}\text { surgical aneurysm trapping, } \\
\text { partial resection }\end{array}$ & $\begin{array}{l}\text { rt hemiparesis, rt } \\
\text { hemianopsia }\end{array}$ \\
\hline $\begin{array}{l}\text { Whittle et al., } \\
1982\end{array}$ & $59, \mathrm{M}$ & It MCA & $5 \times 3$ & $\begin{array}{l}\text { HA, seizure, faciobrachial paresis, } \\
\text { dysphasia }\end{array}$ & aneurysm wrapping & died \\
\hline \multirow{2}{*}{$\begin{array}{l}\text { Vlahovitch et al., } \\
1985\end{array}$} & $32, F$ & It ICA & & & anastomosis, ICA occlusion & \\
\hline & $48, M$ & PCoA & $6 \times 1.7$ & & parent vessel occlusion & \\
\hline Chang et al., 1986 & $20, \mathrm{M}$ & rt PCA & & HA, It hemiparesis, It hemianopsia & $\begin{array}{l}\text { STA-PCA anastomosis, aneu- } \\
\text { rysm trapping \& resection }\end{array}$ & neurologically intact \\
\hline Terada et al., 1988 & $50, \mathrm{M}$ & It VA & $\begin{array}{l}1.7 \times 2.5 \\
\times 1.5\end{array}$ & HA, diplopia, & none & $\begin{array}{l}\text { died of intracranial } \\
\text { hemorrhage }\end{array}$ \\
\hline Li et al., 1988 & $27, \mathrm{~F}$ & rt MCA & $8 \times 7 \times 6$ & $\begin{array}{l}\text { HA, dysarthria, central CN VII } \\
\text { palsy, It hemiparesis }\end{array}$ & resection & neurologically intact \\
\hline Belec et al., 1988 & $69, F$ & It PCA & $\begin{array}{l}6 \times 4 \\
\times 4.5\end{array}$ & $\begin{array}{l}\text { dysphasia, rt hemianopsia, rt } \\
\text { hemiparesis }\end{array}$ & none & died \\
\hline $\begin{array}{l}\text { Haddad \& Haddad, } \\
1988\end{array}$ & $53, F$ & It MCA & $\begin{array}{l}3.5 \times 2 \\
\times 5\end{array}$ & seizure & $\begin{array}{l}\text { surgical aneurysm trapping \& } \\
\text { resection }\end{array}$ & $\begin{array}{l}\text { minimal rt hand fine } \\
\text { motor dysfunction }\end{array}$ \\
\hline \multirow[t]{2}{*}{ Sugita et al., 1988} & $51, \mathrm{~F}$ & rt VA & 4.5 & $\begin{array}{l}\mathrm{HA} \text {, lower } \mathrm{CN} \text { dysfunction, It hemi- } \\
\text { paresis, truncal ataxia, nystagmus }\end{array}$ & $\begin{array}{l}\text { VA occlusion test followed by } \\
\text { surgical trapping \& resection }\end{array}$ & $\begin{array}{l}\text { improvement of neu- } \\
\text { rological findings }\end{array}$ \\
\hline & $61, \mathrm{M}$ & It VA & 3.5 & HA, dysarthria, It hemiparesis & $\begin{array}{l}\text { proximal ligation, then distal } \\
\text { ligation \& resection }\end{array}$ & $\begin{array}{l}\text { unchanged neurologi- } \\
\text { cal findings }\end{array}$ \\
\hline \multirow{2}{*}{$\begin{array}{l}\text { Kumabe et al., } \\
1990\end{array}$} & $39, \mathrm{M}$ & It MCA & 5 & rt ocular pain & none & died \\
\hline & $53, F$ & It PCA & 2.5 & $\begin{array}{l}\text { HA, diplopia, rt medial longitudi- } \\
\text { nal fasciculus syndrome }\end{array}$ & none & died \\
\hline
\end{tabular}




\section{Giant serpentine aneurysms}

TABLE 1: Summary of data obtained in a literature review of cases involving giant serpentine aneurysms (continued)*

\begin{tabular}{|c|c|c|c|c|c|c|}
\hline $\begin{array}{l}\text { Authors \& } \\
\text { Year }\end{array}$ & $\begin{array}{l}\text { Age (yrs), } \\
\text { Sex }\end{array}$ & Location & $\begin{array}{l}\text { Size } \\
(\mathrm{cm})\end{array}$ & Presentation & Treatment & Outcome \\
\hline $\begin{array}{l}\text { Suzuki et al., } \\
1992\end{array}$ & $39, \mathrm{M}$ & rt MCA & $\begin{array}{c}6.5 \times \\
3.7 \times 4\end{array}$ & HA, partial CN VI palsy & STA-MCA bypass & neurologically intact \\
\hline $\begin{array}{l}\text { Horowitz et } \\
\text { al., } 1994\end{array}$ & $19, \mathrm{M}$ & It MCA & 6 & seizure & $\begin{array}{l}\text { sodium amytal testing, STA-MCA } \\
\text { bypass, clipping of the parent vessel } \\
\text { distal to the aneurysm }\end{array}$ & $\begin{array}{l}\text { neurologically intact w/ throm- } \\
\text { bosed aneurysm at 18-mo } \\
\text { follow-up }\end{array}$ \\
\hline $\begin{array}{l}\text { Isla et al., } \\
1994\end{array}$ & $37, M$ & It MCA & $\begin{array}{c}10 \times 4 \\
\times 4\end{array}$ & $\begin{array}{l}\text { seizure; recurrence: dyspha- } \\
\text { sia, lethargy, rt hemiparesis }\end{array}$ & $\begin{array}{l}\text { STA-MCA bypass \& ICA ligation; } \\
\text { recurrence after } 2 \text { years: clipping of It } \\
\text { MCA \& aneurysm resection }\end{array}$ & mild aphasia, rt hemiparesis \\
\hline \multirow[t]{5}{*}{$\begin{array}{l}\text { Aletich et al., } \\
1995\end{array}$} & $44, \mathrm{~F}$ & rt MCA & $\begin{array}{c}4.5 \times 4 \\
\times 3.7\end{array}$ & seizure & none & $\begin{array}{l}\text { spontaneous thrombosis of } \\
\text { aneurysm, no neurological } \\
\text { deficits }\end{array}$ \\
\hline & $34, F$ & rt MCA & $\begin{array}{c}6 \times 4.5 \\
\times 4\end{array}$ & $\begin{array}{l}\text { HA, seizure, It hemiparesis, It } \\
\text { hemianopsia }\end{array}$ & $\begin{array}{l}\text { endovascular occlusion of feeder w/ } \\
\text { helical coils \& bucrylate }\end{array}$ & neurologically intact \\
\hline & $44, \mathrm{M}$ & rt VA & $5 \times 4$ & $\begin{array}{l}\text { loss of motor control of rt } \\
\text { hand, peripheral CN VII palsy, } \\
\text { rt decreased motor tone }\end{array}$ & ligation rt VA & clinical recovery \\
\hline & $20, M$ & rt ICA & $\begin{array}{c}5.5 \times \\
4.5\end{array}$ & rt optic nerve neuropathy & $\begin{array}{l}\text { STA-MCA anastomosis, balloon oc- } \\
\text { clusion ICA \& ophthalmic artery }\end{array}$ & $\begin{array}{l}\text { complete thrombosis of aneu- } \\
\text { rysm, neurologically intact }\end{array}$ \\
\hline & $14, \mathrm{M}$ & It MCA & $\begin{array}{l}10 \times 9 \\
\times 8\end{array}$ & neurologically intact & $\begin{array}{l}2 \text { stage: 1) double It STA-MCA } \\
\text { bypass, distal aneurysm clipping; 2) } \\
\text { proximal clipping \& thrombectomy }\end{array}$ & neurologically intact \\
\hline \multirow{13}{*}{$\begin{array}{l}\text { Mawad \& } \\
\text { Klucznik, } \\
1995\end{array}$} & & rt PCA & & & $\begin{array}{l}\text { endovascular occlusion of parent ves- } \\
\text { sel with Guglielmi detachable coils }\end{array}$ & \\
\hline & & It PCA & & & $\begin{array}{l}\text { endovascular occlusion of parent ves- } \\
\text { sel with Guglielmi detachable coils }\end{array}$ & It temporooccipital infarct \\
\hline & & rt ICA & & & $\begin{array}{l}\text { BTO, detachable balloon occlusion of } \\
\text { parent vessel }\end{array}$ & \\
\hline & & It ICA & & & $\begin{array}{l}\text { BTO, detachable balloon occlusion of } \\
\text { parent vessel }\end{array}$ & \\
\hline & & It MCA & & & $\begin{array}{l}\text { endovascular occlusion } w / \text { liquid } \\
\text { adhesive deposited at the origin of the } \\
\text { residual channel }\end{array}$ & transient aphasia \\
\hline & & It MCA & & & $\begin{array}{l}\text { Wada test, endovascular occlusion w/ } \\
\text { liquid adhesive deposited at the origin } \\
\text { of the residual channel }\end{array}$ & aphasia \\
\hline & & rt PICA & & & $\begin{array}{l}\text { endovascular occlusion } w / \text { liquid } \\
\text { adhesive deposited at the origin of the } \\
\text { residual channel }\end{array}$ & \\
\hline & & VBJ & & & & \\
\hline & & It MCA & & & & \\
\hline & & rt ICA & & & & \\
\hline & & rt MCA & & & & \\
\hline & & It PCA & & & & \\
\hline & & It MCA & & & & \\
\hline $\begin{array}{l}\text { Bakac et al., } \\
1997\end{array}$ & $17, \mathrm{~F}$ & rt MCA & $\begin{array}{c}4 \times 3 \times \\
2.5\end{array}$ & $\begin{array}{l}\text { HA, rt ptosis, meningismus, } \\
\text { SAH }\end{array}$ & $\begin{array}{l}\text { proximal \& distal clipping of the aneu- } \\
\text { rysm \& resection }\end{array}$ & $\begin{array}{l}\text { neurologically intact, aneu- } \\
\text { rysm formation on another } \\
\text { MCA branch that was clipped }\end{array}$ \\
\hline $\begin{array}{l}\text { Vishteh \& } \\
\text { Spetzler, } 1999\end{array}$ & $41, M$ & VBJ & & brainstem ischemia & none & "locked-in" state \\
\hline
\end{tabular}


TABLE 1: Summary of data obtained in a literature review of cases involving giant serpentine aneurysms (continued)*

\begin{tabular}{|c|c|c|c|c|c|c|}
\hline $\begin{array}{l}\text { Authors \& } \\
\text { Year }\end{array}$ & $\begin{array}{l}\text { Age (yrs) } \\
\text { Sex }\end{array}$ & Location & $\begin{array}{l}\text { Size } \\
(\mathrm{cm})\end{array}$ & Presentation & Treatment & Outcome \\
\hline $\begin{array}{l}\text { Lee et al., } \\
1999\end{array}$ & $18, F$ & It PCA & & $\begin{array}{l}\mathrm{HA} \text {, thrombosed aneurysm } \\
\text { recanalizing over 3-wk period }\end{array}$ & surgical aneurysm trapping & transient CN III palsy \\
\hline \multirow[t]{2}{*}{$\begin{array}{l}\text { Otsuka et al., } \\
2001\end{array}$} & $48, M$ & rt ICA & 4 & It hemianopsia, It hemiparesis & $\begin{array}{l}\text { endovascular coil deployment w/in } \\
\text { aneurysm lumen }\end{array}$ & It hemianopsia, It hemiparesis \\
\hline & $10, M$ & rt VA & $\begin{array}{c}2 \times 4 \\
\times 4\end{array}$ & $\mathrm{HA}$, tetraparesis & $\begin{array}{l}\text { BTO, endovascular coil \& glue deploy- } \\
\text { ment w/in aneurysm lumen }\end{array}$ & $\begin{array}{l}\text { gradually improving tetrapa- } \\
\text { resis }\end{array}$ \\
\hline \multirow[t]{2}{*}{$\begin{array}{l}\text { Coley et al., } \\
2002\end{array}$} & $43, M$ & rt PCA & & $\mathrm{HA}$ & $\begin{array}{l}\text { endovascular coil deployment w/in the } \\
\text { proximal aneurysm lumen \& parent } \\
\text { artery }\end{array}$ & neurologically intact \\
\hline & $33, \mathrm{M}$ & PCA & $\begin{array}{l}3 \times 2.5 \\
\times 2.5\end{array}$ & seizure & $\begin{array}{l}\text { endovascular coil deployment w/in } \\
\text { aneurysm lumen }\end{array}$ & neurologically intact \\
\hline $\begin{array}{l}\text { Fanning et al., } \\
2003\end{array}$ & $30, M$ & It ICA & & $\begin{array}{l}\mathrm{HA} \text {, blurred vision, It CN VI } \\
\text { palsy, It eye blindness }\end{array}$ & $\begin{array}{l}\text { BTO, detachable balloon occlusion of } \\
\text { parent vessel }\end{array}$ & $\begin{array}{l}\text { unchanged neurological } \\
\text { findings }\end{array}$ \\
\hline $\begin{array}{l}\text { Sari et al., } \\
2006\end{array}$ & $24, \mathrm{M}$ & It MCA & $\begin{array}{c}5 \times 6 \times \\
5.5\end{array}$ & $\mathrm{HA}$ & none & $\begin{array}{l}\text { neurologically intact, sponta- } \\
\text { neous thrombosis over } 3-y r \\
\text { follow-up }\end{array}$ \\
\hline $\begin{array}{l}\text { Amin-Hanjani } \\
\text { et al., } 2006\end{array}$ & $14, \mathrm{M}$ & MCA & & $\mathrm{HA}$ & $\begin{array}{l}\text { STA-MCA bypass \& clipping of parent } \\
\text { artery }\end{array}$ & $\begin{array}{l}\text { transient hemiparesis, } \\
\text { neurologically intact at 13-yr } \\
\text { follow-up }\end{array}$ \\
\hline $\begin{array}{l}\text { Mahadevan et } \\
\text { al., } 2008\end{array}$ & $16, M$ & VBJ & & $\begin{array}{l}\text { HA, dysarthria, CN VI \& VII } \\
\text { palsy, gait ataxia }\end{array}$ & none & died \\
\hline \multirow[t]{3}{*}{$\begin{array}{l}\text { Van-Rooij } \\
\text { et al., } \\
2008\end{array}$} & $16, M$ & rt ACA & & HA, lethargy, SAH & $\begin{array}{l}\text { BTO, endovascular occlusion of par- } \\
\text { ent vessel w/ Guglielmi detachable } \\
\text { coils }\end{array}$ & neurologically intact \\
\hline & $68, \mathrm{~F}$ & It MCA & & transient dysphasia & $\begin{array}{l}\text { BTO, endovascular coil occlusion of } \\
\text { aneurysm lumen }\end{array}$ & $\begin{array}{l}\text { transient dysphasia, } \\
\text { neurologically intact at 3-mo } \\
\text { follow-up }\end{array}$ \\
\hline & $51, \mathrm{~F}$ & It ACA & & frontal syndrome & $\begin{array}{l}\text { BTO, endovascular aneurysm lumen } \\
\text { occlusion w/ glue, resection of throm- } \\
\text { bosed aneurysm }\end{array}$ & neurologically intact \\
\hline
\end{tabular}

* $\mathrm{CN}=$ cranial nerve; $\mathrm{HA}$ = headache; $\mathrm{PICA}=$ posterior inferior cerebellar artery; $\mathrm{PCOA}=$ posterior communicating artery; $\mathrm{POD}=$ postoperative day; $\mathrm{VA}=$ vertebral artery; $\mathrm{VBJ}=$ vertebrobasilar junction.

flow toward one wall rather than continue through the central portion of the aneurysm. ${ }^{12}$ Fanning et al ${ }^{11}$ have called this wavy, sinusoidal angiographic appearance the pretzel sign. Serpentine aneurysms have separate points at which channels enter and exit the lesion, which differentiates this subcategory of giant aneurysms from saccular aneurysms, which have only one entry and exit point at the neck. ${ }^{1,11}$ The exiting channel of the serpentine aneurysm feeds the distal branches of the parent artery from which the aneurysm originates and supplies normal brain parenchyma (Fig. 1). ${ }^{11,25}$ As previously noted, the rate of blood flow through the aneurysm is slow. ${ }^{1,5,11,20,24,39,44}$ Mass effect from the thrombosed portion of the aneurysm is almost always present, which is indicated on angiography by displaced surrounding vessels and occasionally midline shift. 5,33,39,44

Similar to the findings of Segal and McLaurin, ${ }^{39}$ the majority of giant serpentine aneurysms are located within the MCA territory. A comprehensive literature review, including manuscripts reporting on serpentine aneurysms, noted $30(50 \%)$ in the MCA circulation, $11(18 \%)$ in the PCA circulation, 9 (15\%) within the vertebral artery or vertebrobasilar junction, $8(13 \%)$ within the ICA, and 2 (3\%) within the ACA (Table 2). The hypothesis for the significant occurrence within the MCA territory compared with the ICA is two-fold. First, there is significant jet force of the blood flow through the ICA, preventing stagnation of blood and hence preventing the formation of thrombus, whereas in the MCA the blood flow jet force is lower and blood is more likely to stagnate and form thrombus. ${ }^{12}$ Second, there are no dural or osseous structures to limit expansion of the aneurysm..$^{12,24}$

Computed tomography scanning demonstrates a well-circumscribed mass lesion with surrounding edema 
TABLE 2: Distribution of giant serpentine aneurysms by location based on the literature review

\begin{tabular}{cc}
\hline Involved Artery & Percentage \\
\hline MCA & 50 \\
PCA & 18 \\
VA or VBJ & 15 \\
ICA & 13 \\
ACA & 3 \\
\hline
\end{tabular}

often misdiagnosed as a neoplasm..$^{5,29,33}$ The aneurysm is heterogeneous in appearance, the high density area represents the aneurysmal thrombus, and the low density region represents the patent vascular channel. ${ }^{29,33}$ The hyperdense, thrombosed portion of the aneurysm may also be heterogeneous, indicating different stages of hemorrhage and thrombosis. Additionally, a thin peripheral rim of calcification may be noted surrounding the aneurysm, indicating the chronic nature of giant serpentine aneurysms. ${ }^{21,29}$ Postcontrast CT scanning demonstrates intense homogeneous enhancement of the serpiginous vascular lumen and of the peripheral rim of the aneurysm, while the thrombosed portion of the aneurysm is nonenhancing, which has been coined the "target sign" by Kricheff. ${ }^{23}$ The target sign is pathognomonic for partially thrombosed aneurysms. ${ }^{1,5,22,23,29,33}$ Signs of mass effect including midline shift, effacement of the ventricular system, and surrounding edema are also noted, as in Fig. 2.

Magnetic resonance imaging findings have not been as clearly defined as those in other modalities. Reported findings have included heterogeneous hyperintensity on T1-weighted imaging indicating blood products of vary-

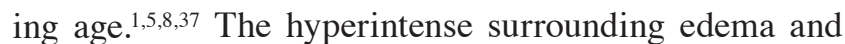
the hypointense flow void associated with the serpiginous vascular lumen are routinely demonstrated on T2-weighted imaging. ${ }^{1}$ The results of contrast-enhanced MR imaging are conflicting, and no consistent pattern has been determined. . $^{1,5,8,37}$

Other radiographic modalities have characteristic findings for giant serpentine aneurysms, but they can be misleading. Radiography of the head may demonstrate curvilinear calcifications as a result of calcified thrombosis within the aneurysm..$^{33,39}$ Erosive osseous changes may be noted within the clinoid process, sella turcica, sphenoidal fissure, or other basal structures. ${ }^{33}$

Pathological studies of giant serpentine aneurysms, obtained postoperatively and postmortem, have been instrumental in defining this entity. In Segal and McLaurin's landmark paper, ${ }^{39}$ the authors published the pathological findings of both cases. Their findings included large globoid masses that contained an irregular serpentine channel coursing through a partially thrombosed aneurysm. They also noted multiple small, irregular channels that ended in blind pouches, in addition to the patent, serpentine channel. Sections through the thrombosed portion of the aneurysm demonstrated a laminated clot. ${ }^{39}$ The walls of the aneurysms were notably thicker than usual, measuring 1-3 $\mathrm{mm}$, and were composed primarily of acellular, fibrous tissue; no internal elastic lamina or endothelial lining could be identified. ${ }^{39}$ Additional reports have documented hemosiderin and calcification within the walls of serpentine aneurysms. ${ }^{5,8,12}$ In 1 specimen, arterial vessels were seen coursing through the adventitia of the aneurysm and supplying the outer surface of the mass, similar to a vasa vasorum. This is likely the source of enhancement of the aneurysmal rim on CT

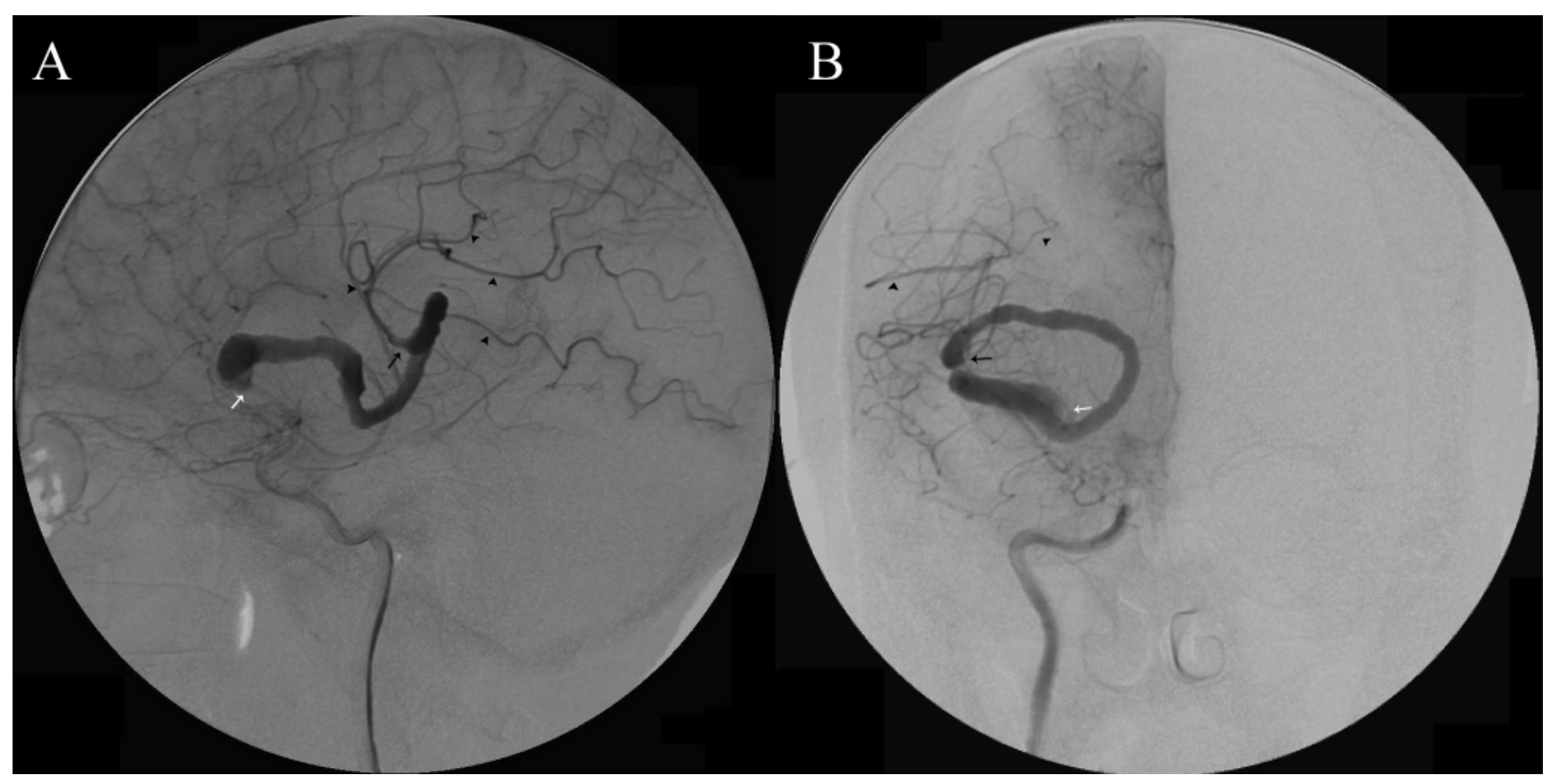

FIG. 1. Lateral (A) and anteroposterior (B) cerebral angiograms demonstrating a serpentine aneurysm within the MCA aneurysm. The white arrow indicates the entrance point of the aneurysm off the proximal MCA. The black arrow points to the exiting channel of the aneurysm that is supplying normal cortical vessels of the MCA denoted by the arrowheads. 


\section{D. Christiano et al.}

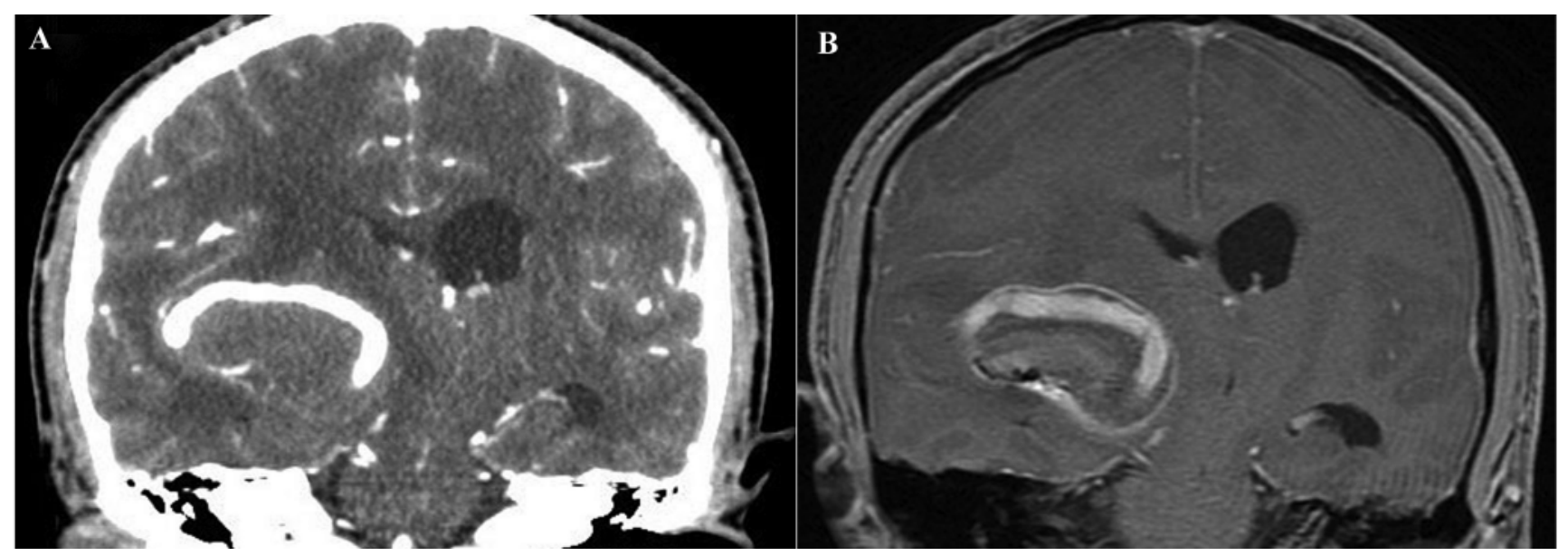

FIG. 2. Coronal CT (A) and MR (B) images of the head with contrast demonstrating an enhancing vascular channel eccentrically located within a giant thrombosed aneurysm. A thin rim of enhancement can be seen along the outer rim of the aneurysm. Midline shift and effacement of the right lateral ventricle are also present.

scans. Segal and McLaurin also noted that neither of the aneurysms originated from the apical medial gap found at the arterial forking, like that which is found commonly in saccular aneurysms. ${ }^{39}$ Similar pathological findings have been published by other authors. ${ }^{5,12,14,20,24,41,44}$

The origin of giant serpentine aneurysms is still uncertain. Because these aneurysms do not present at arterial branch points as do typical saccular aneurysms and because they have different clinical presentations, they may represent a different pathophysiology; thus, serpentine aneurysms are different from saccular aneurysms. Theories of origin in the literature include: development of giant serpentine aneurysms from saccular aneurysms by a "contained expansion" 27,30 process, by fusiform dilation of the parent vessel with thrombosis,${ }^{44}$ by repeated dissection of the intrinsic vessel wall with intramural hemorrhages,${ }^{9}$ and by weakening of the vessel wall either congenital, ${ }^{41,44,50}$ hemodynamically induced degeneration of the vascular wall, ${ }^{45}$ or as a result of a degenerative connective tissue disease of the arterial wall. ${ }^{20}$

\section{Natural History}

Giant serpentine aneurysms are dynamic entities. Often, a giant serpentine aneurysm comes to the attention of healthcare providers once it has grown to a substantial size and resulted in neurological deficits or seizures due to its mass effect. ${ }^{1,11,25,29,39}$ In a review by Suzuki et al., ${ }^{41} 12$ $(30 \%)$ of 39 patients had radiographic evidence of aneurysm enlargement over a period of 26 days -5 years. Various mechanisms of growth have been proposed including accumulation of thrombotic material, recurrent intramural hemorrhage, and development of intrathrombotic capillary channels. ${ }^{8,12,25}$

The eccentric serpentine channel formation and accumulation of thrombotic material is a result of the Coanda effect, which was first described by Fodstad et al. ${ }^{12}$ This hemodynamic principle describes the tendency for a jet of flowing blood to be deflected and preferentially flow toward one wall of a vascular channel, rather than continue to course through the center of the channel. Fluid pressure changes along the jet stream reinforce the eccentric path of blood flow along one arterial wall. ${ }^{12,24}$ Blood flow is then significantly decreased in the central portion of the aneurysm and adjacent arterial wall, which predisposes for stagnant blood flow and thrombus formation. As a thrombus accumulates, the aneurysm morphology evolves and enlarges.

Giant serpentine aneurysms contain partial thrombus. However, the question that remains is in what stage of aneurysm maturation the thrombus exists? Sari et al. ${ }^{37}$ have documented a case of spontaneous and complete thrombosis of a giant serpentine aneurysm. The patient presented with new-onset headaches. An angiogram obtained the next day was diagnostic for giant serpentine aneurysm. However, when the patient was brought back to the angiography suite 2 weeks later for treatment, the aneurysm was completely thrombosed. The patient was neurologically intact at the time of publication, and follow-up angiography at 3 years demonstrated continued occlusion.

In contrast, there are case reports in the literature describing rapid neurological decline leading to death after ischemic stroke within the territory supplied by the giant serpentine aneurysm. ${ }^{28}$ Two different mechanisms have been proposed: one consideration is the aneurysmal thrombus causes stretching or compression of the parent vessel, resulting in occlusion of that parent vessel; the other consideration is that the rapid narrowing of the residual serpentine channel within the aneurysm, due to acute thrombus accumulation, limits flow to the potentially dependent distal cortical vessels. ${ }^{25}$ The clinical outcome after occlusion of giant serpentine aneurysms is likely to depend on the speed at which the residual serpentine channel narrows and the degree to which the collateral circulation develops. ${ }^{25}$

Complete thrombosis of giant serpentine aneurysms should not be considered the final stage of this dynamic entity, however. Lee et al. ${ }^{25}$ have described the case of a young woman presenting with headache and ptosis. Angiography demonstrated an avascular mass within the interpeduncular cistern and occlusion of the PCA distal 


\section{Giant serpentine aneurysms}

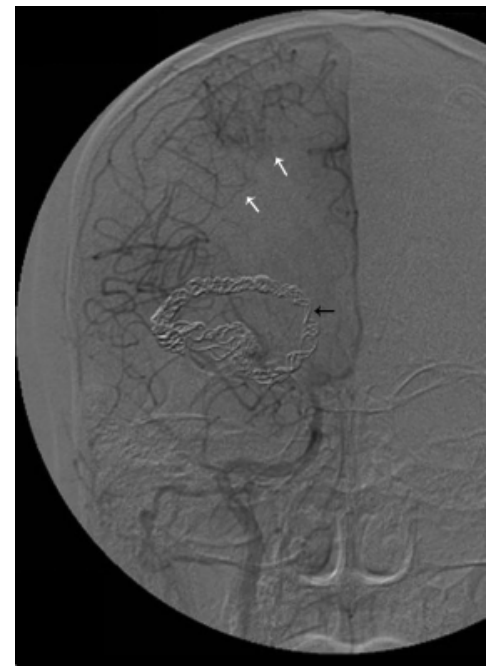

FIG. 3. Anterposterior cerebral angiogram of the right MCA. The coil mass (black arrow) is noted occluding the serpentine channel. Additionally, collateral circulation (white arrows) between the ACA and inferior division of the MCA are perfusing the area previously supplied by the serpentine aneurysm.

to the $\mathrm{P}_{1}$ segment secondary to mass effect. The distal PCA was supplied by the transcortical collateral circulation. Both CT and MR imaging confirmed the presence of a completely thrombosed giant serpentine aneurysm. This same patient presented 3 weeks later with progressive headaches, and recanalization was confirmed by repeat angiography demonstrating the presence of a patent serpentine channel within the now partially thrombosed aneurysm. This case demonstrates the varying nature of giant serpentine aneurysms and raises the question: What is the final stage of this dynamic process?

The natural history of giant serpentine aneurysms also includes hemorrhage. Interestingly, Suzuki et al. ${ }^{41}$ have reported that $28 \%$ of patients with giant serpentine aneurysms initially present with SAH. This conflicts with the literature, which accounts for the majority of the presentations being secondary to mass effect brought on by growth of the aneurysm. ${ }^{1,39}$ In other studies, the thickened wall associated with serpentine aneurysms has been postulated as a source of protection against SAH..$^{20,39}$

Suzuki et al. ${ }^{41}$ have also reported very poor results associated with conservative management of giant serpentine aneurysms. They reviewed 18 cases of giant serpentine aneurysms within the MCA territory. Twelve patients were treated with surgical alteration of blood flow and 6 were treated conservatively. Of the 6 treated conservatively, 1 remained clinically unchanged and the other 5 suffered, deteriorated, or died. ${ }^{41}$ Of the 12 who underwent surgical treatment to address the aneurysm and distal/cortical blood supply, all had an improved outcome. ${ }^{41}$ This also suggests that there is a dynamic nature to the pathophysiology of giant serpentine aneurysms for which aggressive treatment should be considered the standard of care.

\section{Preoperative Evaluation}

As a majority of patients with giant serpentine aneu-

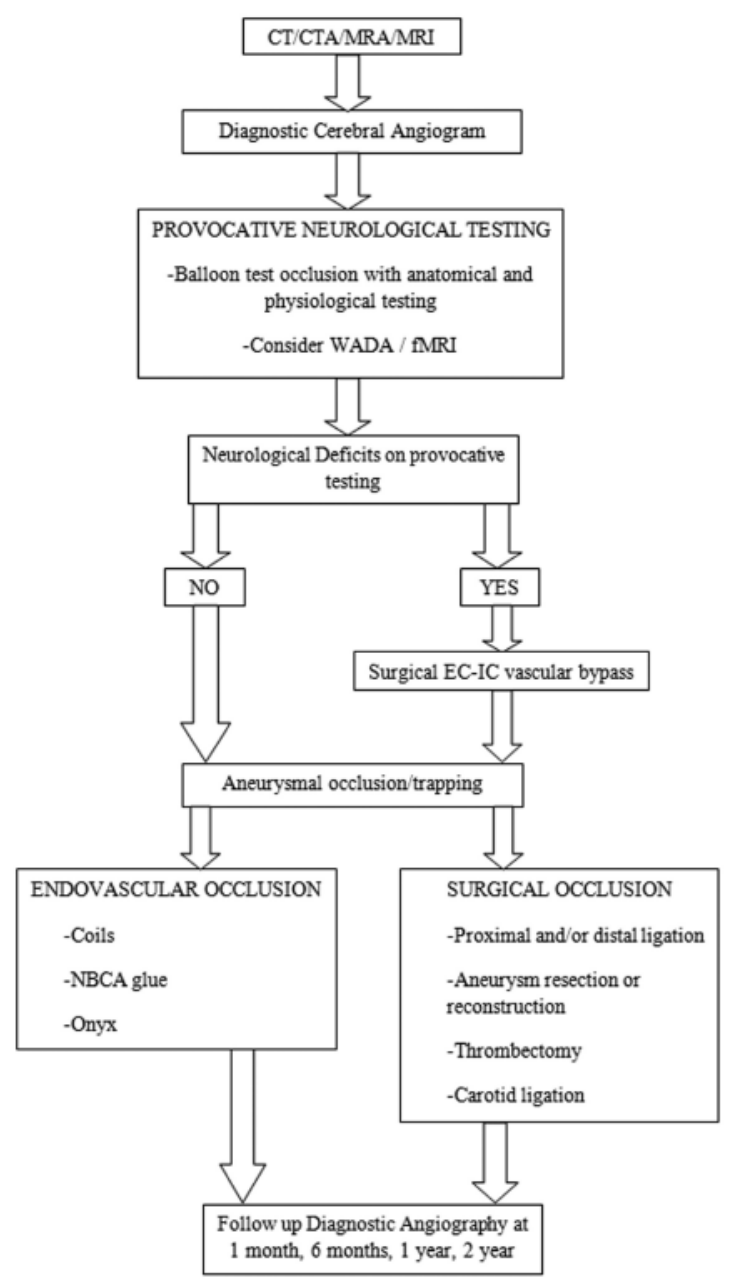

FIG. 4. A flow diagram demonstrating the management of giant serpentine aneurysms. Abbreviations: EC-IC = extracranial-intracranial; $\mathrm{NBCA}=\mathrm{N}$-butyl cyanoacrylate.

rysms present with signs of mass effect, the first diagnostic study obtained is a CT scan of the head. Additional diagnostic studies may be obtained to help define the aneurysm including contrast-enhanced CT scan, CT angiogram, MR image, contrast-enhanced MR image, and MR angiogram. The gold standard, however, remains the cerebral angiogram.

Assessment of distal collateral flow is of utmost importance. Failure to do so results in untoward complications and neurological deficits, $, 36,40,43,44$ which can be avoided by provocative neurological testing via BTO, Wada testing, or functional MR imaging. Collateral supply tolerance testing is done by selective temporary BTO test. This is done to evaluate a patient's ability to tolerate permanent occlusion of the artery as evidenced by ischemia to the distal segment upon occlusion. At our institution, patients are placed in a state of general anesthesia and baseline EEG data are documented prior to occlusion. A compliant Hyperglide or Hyperform balloon (ev3 Inc.) is advanced into the parent vessel just proximal to the aneurysm under radiographic guidance and then inflated during digital subtraction angiography in which a road- 


\section{D. Christiano et al.}

mapped image of the parent vessel is used. During BTO for ICA occlusion, anatomical and physiological testing are performed to verify the occlusion test. In the anatomical portion, we evaluate collateral filling of the occluded side through the circle of Willis. We also measure the transit time to capillary phase, which should demonstrate $<1$-second difference between the 2 hemispheres. In the physiological portion, neurological examination and EEG monitoring are performed serially. If the patient passes both the anatomical and physiological portions at 15 minutes, we then institute a hypotensive challenge by bringing the mean arterial blood pressure to two-thirds that of baseline and again monitoring the circulation and capillary phases on angiography and EEG for an additional 10 minutes. Any change or deterioration in EEG status or prolonged capillary phase on angiography constitutes a failed test. For BTO in other regions, such as the MCA, a Hyperglide balloon is placed proximal to the aneurysm. Anatomical assessments are preformed to search for ACA-MCA and PCA-MCA collaterals both ipsi- and contralaterally. If retrograde filling is seen, a hypotensive challenge is then performed. The predictive value of the BTO may be enhanced by qualitative cerebral blood flow

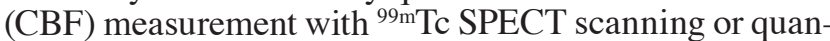
titatively by Xe CT or CT perfusion imaging. These tests, however, require transporting the patient to a different location to perform these tests, and no consensus has been reached as to whether they add value to the BTO.

In some cases, such as aneurysms arising from the $\mathrm{P}_{2}$ segment, Coley et al. ${ }^{8}$ have advocated not performing the BTO before endovascular obliteration, because they thought it carried increased risk of damaging the proximal segment and its eloquent perforators, because of the risk of retrograde thrombosis secondary to the injured endothelium from the balloon occlusion, and because of the increased risk of distal thromboembolism. A literature search of BTO-related complications showed a transient neurological deficit in the range of $7-10 \%$ and severe permanent deficit in 1.5-5\%.13,18,19 Late neurological deficits in patients who had passed a temporary BTO is attributed to cerebrovascular insufficiency and distal thromboembolism from BTO. ${ }^{47}$

Neurological eloquence of the area is assessed by the standard Wada testing before permanent occlusion/treatment of the aneurysm..$^{29}$ However, some doubt the reliability of Wada testing due to the potential changes in collateral blood flow after aneurysm occlusion. The treatment algorithm used at our institution is shown in Fig. 4.

\section{Treatment of Giant Serpentine Aneurysms: Surgical Management}

Studies evaluating conservative management of giant serpentine aneurysms have demonstrated that these aneurysms grow, result in neurological deterioration, and ultimately lead to death if left untreated. ${ }^{41}$ Surgical treatment of giant serpentine aneurysms, however, is complex. The aneurysm neck is broad and often difficult if not impossible to visualize. The neck and proximal parent vessel may not be accessible due to the large size of the aneurysm and significant brain retraction required to obtain proximal control. The perforating vessels may be difficult to visualize and separate from the parent vessel during proximal clip placement. Lastly, the rich vascular supply coursing through the surface of the aneurysm, similar to a vasa vasorum, can cause significant blood loss during the surgery. Each individual case must be considered carefully, taking into account the location, presenting symptoms, aneurysm morphology, and distal vasculature. Surgical interventions described in the literature include carotid artery ligation, ${ }^{1,31}$ aneurysm wrapping, ${ }^{39,41}$ aneurysm coating, ${ }^{39,41}$ aneurysm trapping, ${ }^{32}$ aneurysm clipping, ${ }^{1,39}$ thrombectomy, parent vessel clipping, ${ }^{1,39}$ and extracranial-intracranial bypass grafts. . $^{1,16,41}$ The perioperative morbidity and mortality rate for giant serpentine aneurysms was 30-35\% prior to bypass revascularization procedures. ${ }^{1}$

Carotid artery ligation is one of the original surgical techniques for treating aneurysms. ${ }^{35}$ It is, however, associated with a high rate of complications and an incidence of distal ischemic stroke as high as $33 \%$ in some studies. ${ }^{38}$ Fodstad et al. ${ }^{12}$ used carotid artery ligation in the treatment of a giant aneurysm of the cavernous ICA. Three weeks following ligation, the patient presented with an ICA giant serpentine aneurysm. The authors theorized that the flow dynamics within the aneurysm were changed such that the Coanda effect was established, the flow was directed to one side of the arterial wall, and thrombus formed in the central lumen and contralateral arterial wall, thus changing this lesion from a giant aneurysm to a giant serpentine aneurysm. Surgical wrapping or coating of giant serpentine aneurysms has also yielded poor results. Suzuki et al. ${ }^{41}$ noted 2 of 18 patients with MCA giant serpentine aneurysms that underwent lesion coating and wrapping, respectively; both patients died. This method of treatment was considered conservative and the results were poor, suggesting that it should also no longer be used.

The perioperative morbidity and mortality rate for giant serpentine aneurysms was $30-35 \%^{1}$ prior to bypass revascularization procedures. The outflow channel of the aneurysm feeds the distal branches of the parent artery from which the aneurysm originates and supplies normal brain parenchyma. ${ }^{11,25}$ If the brain parenchyma is dependent on the serpentine channel and its vascular supply distally, the patient could suffer severe consequences following aneurysm occlusion. It is now considered a standard of care to determine the dependence of the distal parenchyma on the serpentine channel and the quality of collateral circulation prior to intervention. This may be elucidated via BTO. Measuring the postclipping reduction of cerebral blood flow intraoperatively has also been suggested as a means of evaluating collateral circulation. ${ }^{4}$

If, indeed, the distal cortex is dependent on the vascular supply through the serpentine aneurysm, then surgical revascularization is required. Among the many considerations for this procedure, the initial ones should include the type of bypass needed (STA, saphenous vein, or radial artery) and the caliber of the recipient vessel. For example, the STA-MCA bypass is an excellent procedure for giant serpentine aneurysms in the most common of locations, the MCAs and PCAs. This procedure, however, is not feasible for the ICA because of the limited flow, 
and in that case a high-flow, saphenous vein graft would be better. Each individual case should be considered conditionally, accounting for the location, symptoms, and collateral circulation. Once the end-to-side vascular bypass is established, the aneurysm can be addressed in a 1- or 2-stage procedure. This decision is generally based on institutional philosophy and aneurysm morphology. In a 1-stage procedure, immediately following the vascular bypass the aneurysm is excluded from the circulation via proximal parent vessel clipping and distal parent vessel clipping, with or without thrombectomy, distal parent vessel clipping alone, carotid artery ligation, or immediate endovascular sacrifice. ${ }^{1}$ The philosophy behind a 1-stage procedure is that the patency of the graft depends on the vascular drive, which is achieved by excluding the aneurysm from the circulation. In a 2-stage procedure, the first stage is only the vascular bypass procedure with no attempt to expose or address the aneurysm. An angiogram is then obtained to assess the success of the extracranial-intracranial bypass. The goal of the second stage, on a later day, is to exclude the aneurysm from the circulation. Options for the second stage include proximal parent vessel clipping and distal parent vessel clipping with or without thrombectomy, distal parent vessel clipping alone, carotid artery ligation, and an endovascular means of trapping the aneurysm. ${ }^{1}$ Advocates of the 2 -stage procedure maintain that patency and adequacy of the bypass should be confirmed via angiography prior to aneurysm occlusion. Amin-Hanjani and colleagues ${ }^{2}$ have reported a case of a giant serpentine aneurysm of the MCA treated with STA-MCA bypass and proximal MCA clipping. At 13 years postoperatively, the patient is neurologically intact, the aneurysm remains occluded, and the bypass graft is functional. The authors also noted that the aneurysm sac was shrunken considerably in size but remained as a densely calcified mass. Isla et al. ${ }^{22}$ reported failure of an STA-MCA bypass in a patient with a giant serpentine aneurysm on the posterior branch of the MCA trifurcation. The patient underwent STA-MCA bypass and ipsilateral ICA ligation. At 6 months he was doing well clinically, and angiographically the bypass graft was functional. It was noted, however, that the aneurysm was being fed from the posterior circulation via the posterior communicating artery. At 2 years the patient presented with hemiparesis, aphasia, and seizures. Angiographically, the aneurysm had enlarged significantly and the bypass graft was no longer functional. Two important lessons can be gleaned from this case. First, the continued aneurysm patency seen on the 6-month postoperative angiogram should have been considered more seriously and prompted further treatment. Second, perhaps like Fodstad, ligation of the carotid artery is too indirect a measure to stop blood supply to the distally located aneurysm. Today, options would include clip application distal to the vessel after bypass or completion of the bypass followed by consideration of an endovascular means of occluding proximal blood supply to the aneurysm.

Interestingly, occluding only the distal outflow of the giant serpentine aneurysm has been reported as an effective method of treatment. This seems counterintuitive, with the assumption being that the risk of rupture would increase; however, Horowitz et al. ${ }^{20}$ have proved otherwise. Based on the Bernoulli equation, they proved that because the blood flow through the serpentine channel is slow, the pressure variation between the proximal and distal portion of the aneurysm is insignificant when the outflow is restricted. Therefore, clipping only the vessel distal to the aneurysm posed no increased risk of rupture and instead allowed for retrograde thrombosis of the aneurysm. This method, however, is controversial.

After occlusion of the aneurysm, the mass effect and associated edema decrease. The initial assumption in surgical management of giant serpentine aneurysms has been that the aneurysm was causing mass effect and therefore should be excised. ${ }^{39}$ The aneurysm sac has a rich blood supply from the associated vasa vasorum, which makes the thrombectomy procedure tenuous and bloody. More recent reports have documented a decrease in size of the aneurysm sac, mass effect, and edema $a^{2,32,41}$ due to clot retraction and thrombus resorption. ${ }^{33}$

If the aneurysm is considered inoperable and/or untreatable by endovascular means, some have advocated ventriculoperitoneal shunt placement to relieve symptoms associated with hydrocephalus. ${ }^{1}$ This method, however, does not address the dynamic, progressive nature of giant serpentine aneurysms.

\section{Treatment of Giant Serpentine Aneurysms: Endovascular Management}

Open surgical treatment, as described in the previous section, continues to be the gold standard. More recently, "deconstructive" endovascular strategies-that is, those involving the sacrifice of the parent vessel from which the aneurysm arises-have also been successfully used. In cases in which there is an established adequate collateral supply to the distal segment (through the circle of Willis) or extracranial-intracranial bypass, external carotid artery-ICA anastomosis at the ophthalmic, cavernous and petrous ICA segments, or leptomeningeal support over the convexities, complete aneurysm endovascular obliteration/occlusion has been successfully performed after a trial selective temporary BTO of the parent vessel in the awake patient. . $^{8,46}$

Successful endovascular modalities include the use of Guglielmi detachable coils, , ,10,15,29,46 Trufill orbit coils, ${ }^{46}$ and $N$-butyl cyanoacrylate glue, ${ }^{46}$ Onyx, and permanent detachable balloons, ${ }^{29}$ which are no longer available. It is very important to assess angiographically the uninvolved cervical and cerebral vasculature for additional disease in the form of plaques, other aneurysms, vessel dissection, or fibromuscular dysplasia, which are contraindications for endovascular occlusion therapy. Figure 3 shows a giant serpentine aneurysm containing coils within the serpentine channel; also seen is excellent collateral circulation, preempting the need for a surgical bypass graft.

We recently treated a patient with a giant serpentine aneurysm of the right MCA. The patient presented with a new-onset seizure. Head CT scanning demonstrated a heterogeneous, hyperdense, well-circumscribed mass in the right frontotemporal region (Fig. 2A). There was 9 $\mathrm{mm}$ of right to left midline shift, surrounding edema, and increased ventricular size. He was treated with hy- 


\section{D. Christiano et al.}

pertonic saline, mannitol, Decadron, and a brief period of CSF diversion for progressive mental deterioration. The patient underwent cerebral diagnostic angiography, which demonstrated an elongated serpentine channel off the right $\mathrm{M}_{2}$ branch, the outflow channel of which was supplying distal MCA cortical branches (Fig. 1). A few days later the patient underwent superselective temporary BTO of the distal $\mathrm{M}_{1}$ segment, which demonstrated excellent collateral flow. Given the excellent collateral vascular supply, the entire serpentine channel was occluded with detachable coils (Fig. 3). The patient's mental status improved as the edema abated, and eventually CSF diversion and all medications were stopped. At 6-month follow-up, the patient was neurologically intact. Magnetic resonance imaging demonstrated a significant improvement of the surrounding edema, correction of the midline shift, and a slight decrease in the size of the aneurysm.

Even after successful endovascular embolization of the aneurysm, persistent neurological symptoms attributable to the mass effect of the giant serpentine aneurysm may require resection of the aneurysm and thrombus. ${ }^{1}$ However, there are reports documenting shrinkage of the aneurysm sac and decreased mass effect following occlusion of the aneurysm, ${ }^{2,41}$ as was seen in our case.

\section{Conclusions}

Giant serpentine aneurysms are $\geq 25-\mathrm{mm}$ partially thrombosed aneurysms with a patent, serpiginous vascular channel that courses through the aneurysm. There are separate inflow and outflow channels, of which the outflow channel supplies brain parenchyma in the territory of the parent vessel. Patients with giant serpentine aneurysms present most often with signs of mass effect and/or seizure, and only rarely with SAH. Given the large size, unique neck, and dependent distal vessels, these aneurysms pose a technical challenge in treatment. Initial treatment modalities were focused on surgical obliteration of the aneurysm, but the morbidity and mortality rate was $30-35 \%$ due to ischemia of the distal parenchyma resulting in stroke. Since that time, BTO, Wada testing, and functional MR imaging have been used to evaluate the degree of collateral circulation and risk of stroke. As techniques and technology have evolved, a combination of surgical bypass grafting and endovascular occlusion has demonstrated promising results with lower morbidity and mortality.

\section{Disclosure}

Dr. Prestigiacomo is a consultant for Boston Scientific, Aesculap, and Termopeutix, Inc.; is a stockholder in Micrus Endovascular; and is the recipient of an unrestricted educational grant from Boston Scientific.

\section{References}

1. Aletich VA, Debrun GM, Monsein LH, Nauta HJ, Spetzler RF: Giant serpentine aneurysms: a review and presentation of five cases. AJNR Am J Neuroradiol 16:1061-1072, 1995

2. Amin-Hanjani S, Chen PR, Chang SW, Spetzler RF: Longterm follow-up of giant serpentine MCA aneurysm treated with EC-IC bypass and proximal occlusion. Acta Neurochir (Wien) 148:227-228, 2006
3. Ammerman BJ, Smith DR: Giant fusiform middle cerebral aneurysm: successful treatment ulilizing microvascular bypass. Surg Neurol 7:255-257, 1977

4. Bakac G, Gholkar A, Mendelow AD: Delayed aneurysm formation following surgery for a giant serpentine aneurysm. Br J Neurosurg 11:260-263, 1997

5. Belec L, Cesaro P, Brugieres P, Gray F: Tumor-simulating giant serpentine aneurysm of the posterior cerebral artery. Surg Neurol 29:210-215, 1988

6. Cantu R, Lemay M: A large middle cerebral aneurysm presenting as a bizarre malformation. Br J Radiol 39:317-319, 1966

7. Chang HS, Fukushima T, Takakura K, Shimizu T: Aneurysms of the posterior cerebral artery: report of ten cases. Neurosurgery 19:1006-1011, 1986

8. Coley SC, Hodgson TJ, Jakubowski J: Coil embolization of giant serpentine aneurysms: report of two cases arising from the posterior cerebral artery. Br J Neurosurg 16:43-47, 2002

9. Day AL, Gaposchkin CG, Yu CJ, Rivet DJ, Dacey RG Jr: Spontaneous fusiform middle cerebral artery aneurysms: characteristics and a proposed mechanism of formation. $\mathbf{J}$ Neurosurg 99:228-240, 2003

10. Drake CG, Peerless SJ: Giant fusiform intracranial aneurysms: review of 120 patients treated surgically from 1965 to 1992 . J Neurosurg 87:141-162, 1997

11. Fanning NF, Kelleher MO, Ryder DQ: The pretzel sign: angiographic pattern of tortuous intra-aneurysmal blood flow in a giant serpentine aneurysm. Br J Neurosurg 17:67-71, 2003

12. Fodstad H, Liliequist B, Wirell S, Nilsson PE, Boquist L, Abdul-Rahman A: Giant serpentine intracranial aneurysm after carotid ligation. Case report. J Neurosurg 49:903-909, 1978

13. Fox AJ, Vinuela F, Pelz DM, Peerless SJ, Ferguson GG, Drake $\mathrm{CG}$, et al: Use of detachable balloons for proximal artery occlusion in the treatment of unclippable cerebral aneurysms. J Neurosurg 66:40-46, 1987

14. Fukamachi A, Hirato M, Wakao T, Kawafuchi J: Giant serpentine aneurysm of the posterior cerebral artery. Neurosurgery 11:271-276, 1982

15. Gobin YP, Vinuela F, Gurian JH, Guglielmi G, Duckwiler GR, Massoud TF, et al: Treatment of large and giant fusiform intracranial aneurysms with Guglielmi detachable coils. J Neurosurg 84:55-62, 1996

16. Greene KA, Anson JA, Spetzler RF: Giant serpentine middle cerebral artery aneurysm treated by extracranial-intracranial bypass. Case report. J Neurosurg 78:974-978, 1993

17. Haddad GF, Haddad FS: Cerebral giant serpentine aneurysm: case report and review of the literature. Neurosurgery 23:92-97, 1988

18. Higashida RT, Halbach VV, Dowd C, Barnwell SL, Dormandy B, Bell J, et al: Endovascular detachable balloon embolization therapy of cavernous carotid artery aneurysms: results in 87 cases. J Neurosurg 72:857-863, 1990

19. Higashida RT, Halbach VV, Dowd CF, Barnwell SL, Hieshima GB: Intracranial aneurysms: interventional neurovascular treatment with detachable balloons-results in 215 cases. Radiology 178:663-670, 1991

20. Horowitz MB, Yonas H, Jungreis C, Hung TK: Management of a giant middle cerebral artery fusiform serpentine aneurysm with distal clip application and retrograde thrombosis: case report and review of the literature. Surg Neurol 41:221225,1994

21. Hung MJ, Wang $\mathrm{CH}$, Cherng WJ: Unruptured left ventricular pseudoaneurysm following myocardial infarction. Heart 80:94-97, 1998

22. Isla A, Alvarez F, Roda JM, Munoz J, Morales C, Garcia Blazquez M: Serpentine aneurysm: regrowth after a superficial temporal artery-middle cerebral artery bypass and internal carotid artery ligation: case report. Neurosurgery 34:1072-1074, 1994 
23. Kricheff: Intracranial aneurysms and arteriovenous malformations, in Refresher Course 408, 64th Scientific Assembly and Annual Meeting of the RSNA. Chicago, 1978

24. Kumabe T, Kaneko U, Ishibashi T, Kaneko K, Uchigasaki S: Two cases of giant serpentine aneurysm. Neurosurgery 26:1027-1032, 1990

25. Lee KC, Joo JY, Lee KS, Shin YS: Recanalization of completely thrombosed giant aneurysm: case report. Surg Neurol 51:94-98, 1999

26. Li ZB, Zhao H, Zhang S: Giant serpentine intracranial aneurysm. A case report. Chin Med J (Engl) 101:55-57, 1988

27. Lukin RR, Chambers AA, McLaurin R, Tew J Jr: Thrombosed giant middle cerebral aneurysm. Neuroradiology 10:125129,1975

28. Mahadevan A, Tagore R, Siddappa NB, Santosh V, Yasha TC, Ranga U, et al: Giant serpentine aneurysm of vertebrobasilar artery mimicking dolichoectasia-an unusual complication of pediatric AIDS. Report of a case with review of the literature. Clin Neuropathol 27:37-52, 2008

29. Mawad ME, Klucznik RP: Giant serpentine aneurysms: radiographic features and endovascular treatment. AJNR Am J Neuroradiol 16:1053-1060, 1995

30. Morley TP, Barr HW: Giant intracranial aneurysms: diagnosis, course, and management. Clin Neurosurg 16:73-94, 1969

31. Odom GL, Tindall GT: Carotid ligation in the treatment of certain intracranial aneurysms. Clin Neurosurg 15:101-116, 1968

32. Otsuka G, Miyachi S, Handa T, Negoro M, Okamoto T, Suzuki $\mathrm{O}$, et al: Endovascular trapping of giant serpentine aneurysms by using Guglielmi detachable coils: successful reduction of mass effect. Report of two cases. J Neurosurg 94:836-840, 2001

33. Patel DV, Sherman IC, Hemmati M, Ferguson RJ: Giant serpentine intracranial aneurysm. Surg Neurol 16:402-407, 1981

34. Pinto R, Kricheff II, Butler R, Murali R: Correlation of computed tomographic, angiographic, and neuropathologic changes in giant cerebral aneurysms. Radiology 132:85-92, 1979

35. Polevaya N, Kalani Y, Steinberg G, Tse V: The transition from hunterian ligation to intracranial aneurysm clips: a historical perspective. Neurosurg Focus 20 (6):E3, 2006

36. Sadik A, Budzilovich G, Shulman K: Giant aneurysm of middle cerebral artery. J Neurosurg 22:177-181, 1965

37. Sari A, Kandemir S, Kuzeyli K, Dinc H: Giant serpentine aneurysm with acute spontaneous complete thrombosis. AJNR Am J Neuroradiol 27:766-768, 2006

38. Scott M, Skwarok E: The treatment of cerebral aneurysms by ligation of the common carotid artery. Surg Gynecol Obstet 113:54-61, 1961

39. Segal HD, McLaurin RL: Giant serpentine aneurysm. Report of two cases. J Neurosurg 46:115-120, 1977

40. Sugita K, Kobayashi S, Takemae T, Tanaka Y, Okudera H, Ohsawa M: Giant aneurysms of the vertebral artery. Report of five cases. J Neurosurg 68:960-966, 1988
41. Suzuki S, Takahashi T, Ohkuma H, Shimizu T, Fujita S: Management of giant serpentine aneurysms of the middle cerebral artery-review of literature and report of a case successfully treated by STA-MCA anastomosis only. Acta Neurochir (Wien) 117:23-29, 1992

42. Terada Y, Tomita K, Shinoda T, Iino Y, Yoshiyama N: Giant serpentine aneurysm in a long-term hemodialysis patient. Clin Nephrol 30:164-167, 1988

43. Terao H, Muraoka I: Giant aneurysm of the middle cerebral artery containing an important blood channel: case report. J Neurosurg 37:352-356, 1972

44. Tomasello F, Albanese V, Cioffi FA: Giant serpentine aneurysms: a separate entity. Surg Neurol 12:429-432, 1979

45. Tuna M, Gocer AI, Ozel S, Bagdatoglu H, Zorludemir S, Haciyakupoglu S: A giant dissecting aneurysm mimicking serpentine aneurysm angiographically. Case report and review of the literature. Neurosurg Rev 21:284-289, 1998

46. van Rooij WJ, Sluzewski M, Beute GN: Endovascular treatment of giant serpentine aneurysms. AJNR Am J Neuroradiol 29:1418-1419, 2008

47. Vazquez Añon V, Aymard A, Gobin YP, Casasco A, Ruffenacht $\mathrm{D}$, Khayata $\mathrm{MH}$, et al: Balloon occlusion of the internal carotid artery in 40 cases of giant intracavernous aneurysm: technical aspects, cerebral monitoring, and results. Neuroradiology 34:245-251, 1992

48. Vishteh AG, Spetzler RF: Evolution of a dolichoectatic aneurysm into a giant serpentine aneurysm during long-term follow up. Case illustration. J Neurosurg 91:346, 1999

49. Vlahovitch B, Fuentes JM, Reynaud C, Benbouzid T, Mazariegos R: [Series of 17 cases of giant intracranial aneurysms. Long-term surgical follow-up and hemodynamic effects of arterial occlusions.] Neurochirurgie 31:255-263, 1985

50. Whittle IR, Dorsch NW, Besser M: Spontaneous thrombosis in giant intracranial aneurysms. J Neurol Neurosurg Psychiatry 45:1040-1047, 1982

51. Zicherman J, Roychowdhury S, Demarco JK, Shepard S, Schonfeld S, Keller I, et al: Endovascular treatment of a ruptured giant serpentine aneurysm of the superior cerebellar artery in a patient with a Chiari II malformation. AJNR Am J Neuroradiol 25:1077-1079, 2004

Manuscript submitted January 14, 2009.

Accepted February 11, 2009.

Address correspondence to: Lana D. Christiano, M.D., Department of Neurological Surgery, New Jersey Medical School, University of Medicine and Dentistry of New Jersey, 90 Bergen Street, Suite 8100, Newark, New Jersey 07101. email:docmitchel@yahoo.com. 